\title{
INVOLVEMENT OF GLUTATHIONE IN THE CYTOTOXICITY OF 9-ISOTHIOCYANATOACRIDINE
}

\author{
Helena Paulíkováa, Mária Bajdichováa, Andrea Šovčíkováa, Danica Sabolováb \\ a Department of Biochemistry and Microbiology, Faculty of Chemical and Food Technology, Slovak Technical University, \\ Bratislava \\ ${ }^{b}$ Department of Biochemistry, Faculty of Science, P. J. Šafárik University, Košice \\ e-mail: helena.paulikova@stuba.sk
}

Received: June 10, 2005; Accepted: September 25, 2005

Key words: Isothiocyanate/Thiol/Apoptosis/K562 cells

Isothiocyanates (ITCs) are phytochemicals with promising cancer-preventive potential. To elucidate the mechanism of cytotoxicity of ITCs, their accumulation by cells and the role of intracellular glutathione, fluorescent 9-isothiocyanatoacridine (AcITC) was synthesized. The kinetic parameters for the reactions of AcITC with thiols were estimated and the influence of AcITC on human chronic myeloid leukemia cell line (K562) in regard to intracellular glutathione was studied. Cytotoxicity was evaluated by MTT assay, $\mathrm{IC}_{50}=29.2 \pm 2.5 \mu \mathrm{M}$ ( $48 \mathrm{~h}$ incubation). This acridine derivative was able to induce apoptosis of cells (morphological changes of cells and DNA fragmentation were observed) at least within certain dose that only decreased the level of intracellular glutathione, excessive doses (completely depleted intracellular pool of glutathione) induced necrosis rather than apoptosis. Our results indicated that apoptosis of leukemia cells induced by ITC is possible only if intracellular glutathione is not entirely depleted.

\section{INTRODUCTION}

Isothiocyanates (ITCs) are phytochemicals with promising cancer-preventive potential. ITCs are capable of both inhibiting the formation of a cancer cell and eliminating an existing one by apoptosis ${ }^{1}$. These substances induce cellular stress, and the glutathione is directly involved in this process ${ }^{2-4}$. The accumulation of ITCs depends on cellular GSH level and intracellular conjugation of ITCs with GSH is mainly responsible for ITCs accumulation by cells. The GS-conjugate (dithiocarbamates) are exported from cells across MRPs and converted by the mercapturic acid pathway ${ }^{5}$. Although, until now any evidence of irreversible modification of DNA, RNA, proteins and basic lipid derivatives of membrane by ITCs was found, $\mathrm{Xu}$ and Thornalley ${ }^{3}$ have suggested that the thiocarbamoylation directly or indirectly leads to function activation of proteins of apoptosis pathway. Murata et al..$^{6}$ confirmed that ITCs can induce DNA damage by generation of superoxide radicals. An alternative explanation of a cytotoxicity of ITCs could be related with thioureas, which can be formed by a reaction of ITCs with cellular amines or with aryl- or alkyl amines (a products of spontaneous hydrolysis of ITCs). The weakly acid dithiocarbamates and thioureas uncouple oxidative phosphorylation by dissipation of the proton gradient ${ }^{7,8}$ and uncoupling of oxidative phosporylation can accelerate the apoptosis-induction capacity of ITCs.

To elucidate the mechanism of cytotoxicity of ITCs, their accumulation by cells and the role of intracellular glutathione, fluorescent 9-isothiocyanatoacridine (AcITC) was synthesized and the effects of the ITC on leukemia cells has been investigated.

In the present work the kinetic parameters for the reactions of 9-isothiocyanatoacridine with thiols was estimated and the influence of AcITC on human chronic myeloid leukemia K562 cell line in regard to intracellular glutathione was studied.

\section{MATERIALS AND METHODS}

\section{Chemicals}

The 9-isothiocyanatoacridine (AcITC) was synthesised and characterized by Podhradsky et al. ${ }^{9}$. Propidium iodide (PI), Hoechst 33342, ethidium bromide, Triton $\mathrm{X}-100$, reduced and oxidised forms of glutathione (GSH, GSSG), cysteine (Cys), $N$-acetylcysteine (NAC), 3-(4, 5dimethylthiazol-2-yl)-2, 5-diphenyltetrazolium bromide (MTT), dimethylsulfoxide (DMSO), acetonitrile (ACN), and NADPH were purchased from Sigma-Aldrich Chemie (Germany). EDTA, RNase and proteinase-K were from Serva (Germany). 5,5'-Dithio-bis(2-nitrobenzoic acid) (DTNB)-Ellman reagent was from Merck (Germany) and gluthathione reductase (GR) was from Calbiochem (USA). Other chemicals were purchased from Lachema (Czech Republic). 


\section{Spectrophotometric determination of the second-order rate constants}

Reactivity of the AcITC with respect to thiols was investigated in system containing $50 \mathrm{mM}$ Clark-Lubs buffer, $\mathrm{pH}=6.0-7.0$ containing $30 \%$ of acetonitrile at $25{ }^{\circ} \mathrm{C}$. The kinetic measurements were performed under conditions for a pseudomonomolecular reaction and the reaction rates were measured spectrophotometrically on a PHILIPS instrument (PU 8750 UV/VIS) and $k_{\text {obs }}$ were calculated. The rate constants $\left(k_{2}\left[\mathrm{M}^{-1} \cdot \mathrm{s}^{-1}\right]\right)$ were calculated using the following $\mathrm{pK}_{\mathrm{a}}$ values of sulfhydryl groups: cysteine 8.3 , glutathione $8.8, \mathrm{~N}$-acetylcysteine 9.5 .

\section{Cell culture}

Human leukemia cell line K562 and mice leukemia cell line L1210 were obtained from Dr. Sedlak and Dr. Rauko (Cancer Research Institute, Bratislava, Slovakia). The cell lines were kept in RPMI 1640 medium supplemented with $10 \%$ foetal calf serum (FCS) (Grand Island Biological Co., Grand Island, NY, USA), penicillin (100 $\mu \mathrm{g} / \mathrm{ml})$ and streptomycin $(100 \mu \mathrm{g} / \mathrm{ml})$. The cells were incubated at $37^{\circ} \mathrm{C}$ in a humidified atmosphere of $5 \% \mathrm{CO}_{2}$ : $95 \%$ air. All in vitro experiments were performed during the exponential phase of cell growth.

\section{MTT assay}

Cytotoxic potential of AcITC in the $48 \mathrm{~h}$ experiment and inhibition concentration $\mathrm{IC}_{50}$ was established by tetrazolium-based colorimetric MTT assay. Cells $(2.5 \times$ $10^{4}$ cells/well in volume $200 \mu \mathrm{l}$ ) were seeded in 96-well microtiter plates. After a 44-h exposure by the acridine derivative and $0.1 \%$ methanol containing control, MTT $(50 \mu 1,1.0 \mathrm{mg} / \mathrm{ml})$ was added to each well $\left(4 \mathrm{~h}, 37^{\circ} \mathrm{C}\right)$. Cells were centrifuged, supernatant was discarded and the pellets solubilised in $100 \mu \mathrm{l}$ of DMSO. The MTT- formazan product was estimated by measuring absorbance at $568 \mathrm{~nm}$ in an ELISA plate reader. Fresh stock solutions of substance were prepared in methanol. MTT assay was performed three times in triplicate.

\section{Determination of LMWT and total glutathione levels}

$2 \times 10^{6}$ of total cell amount were prepared for analysis as follows: medium was removed and cells were rinsed with PBS, then lysed by freezing and thawing (three cycles) in $500 \mu$ of $5 \mathrm{mM}$ EDTA and $3.5 \%$ (w/v) sulfosalicilic acid. After centrifugation ( $15 \mathrm{~min}, 2000 \mathrm{~g}, 4{ }^{\circ} \mathrm{C}$ ), acidic supernatant was neutralized by $\mathrm{NaHCO}_{3}$ and low molecular weight thiols (LMWT) were estimated by Ellman's method ${ }^{10}$ and total glutathione ( $\mathrm{tGSH}=\mathrm{GSH}+\mathrm{GSSG}$ ) was determined by recycling assay as previously reported ${ }^{11}$. Briefly, $0.50 \mathrm{ml}$ of neutralized supernatant was added to a $0.47 \mathrm{ml}$ of $0.150 \mathrm{M}$ sodium phosphate buffer ( $\mathrm{pH} 6.2$ ), containing $5 \mathrm{mM}$ EDTA and $0.2 \mathrm{mM}$ NADPH and to $0.02 \mathrm{ml}$ of $10 \mathrm{mM}$ 5,5'-dithiobis(2-nitrobenzoic acid). The assay was initiated by addition of $10 \mu \mathrm{L}$ of glutathione reductase $(470 \mathrm{U} / \mathrm{ml})$. The rate of formation of 5-thio2-nitrobenzoic acid, proportional to total glutathione concentration, was followed at $412 \mathrm{~nm}$ for $5 \mathrm{~min}$ at $25^{\circ} \mathrm{C}$ in spectrophotometer (PU 8750 UV/VIS Scanning
Spectrophotometer PHILIPS). GSH concentration values were calculated from a standard curve and expressed as $\mathrm{nmol} / 10^{6}$ cells.

\section{Detection of apoptotic cells by fluorescence microscopy and morphological changes}

Cells were stained with $10 \mu \mathrm{M}$ of Hoechst 33342 and PI for $10 \mathrm{~min}$ and analyzed under a fluorescence microscope (JENA LUMAR, Carl Zeiss, Germany) ${ }^{12}$. With this method, necrotic cells showed pink-stained nuclei, whereas viable cells showed green and round nuclei stained only with Hoechst 33342. Apoptotic cells exhibited green or pink fragmented small nuclei depending on the disrupted plasma membrane integrity. AcITC is a fluorescent substance (Fig.1) and morphological changes of leukemia cells were examined without Hoechst 33342, using fluorescence microscope with a $378-456 \mathrm{~nm}$ excitation block filter and 420/450 $\mathrm{nm}$ emission filter. Each cell fraction was evaluated by counting $>200$ cells under the fluorescence microscope.

\section{Analysis of DNA fragmentation}

DNA laddering was detected by isolating fragmented DNA using the SDS/proteinase K/RNase A extraction method, which allows the isolation of only fragmented DNA without contaminating genomic DNA. Briefly, cells were washed in cold PBS and lysed in a TE buffer containing $10 \mathrm{mM}$ Tris- $\mathrm{HCl}$ ( $\mathrm{pH}$ 8.0), 1 mM EDTA, 0.5\% Triton $\mathrm{X}-100$ for $20 \mathrm{~min}$ at $4^{\circ} \mathrm{C}$. After centrifugation at $14,000 \times \mathrm{g}$ for $15 \mathrm{~min}$, the supernatant was treated with proteinase $\mathrm{K}(0.5 \mathrm{mg} / \mathrm{ml})$ and $1 \%$ SDS for $1 \mathrm{~h}$ at $50^{\circ} \mathrm{C}$. DNA was extracted twice with buffered phenol and precipitated with $140 \mathrm{mM} \mathrm{NaCl}$ and 2 vol. of ethanol at $-20{ }^{\circ} \mathrm{C}$ overnight. DNA precipitates were washed twice in $70 \%$ ethanol, dissolved in TE buffer, and treated for $1 \mathrm{~h}$ at $37{ }^{\circ} \mathrm{C}$ with RNase A $(2.5 \mathrm{mg} / \mathrm{ml})$. Finally, DNA preparations were electrophoresed in $1.5 \%$ agarose gels, stained with ethidium bromide. Separated DNA fragments (DNA ladders) were visualised on an UV transilluminator and their size was determined by comparison with DNA size markers (from 584 to $2226 \mathrm{bp}$ ).

\section{Statistical analysis}

The results were expressed as mean \pm S.D. of data obtained from three independent experiments. Statistical analysis of differences was carried out by analysis of variance (ANOVA).

\section{RESULTS AND DISCUSSION}

The reactions of isothiocyanates, especially with intracellular thiols ( $S$-esters of $N$-substituted dithiocarbamic acids arise), are responsible for the nature and degree of the influence on the cell viability. The reactivity of AcITC $\left(k_{2}=14.16 \pm 0.21 \mathrm{M}^{-1}\right.$. $\mathrm{s}^{-1}$, for reaction with GSH, $\mathrm{pH} 6.5, \mathrm{t}$ $=25{ }^{\circ} \mathrm{C}$ ) to thiols is high and e.g. phenethylisothiocyanate is approximately 24-time less reactive than AcITC(ref. ${ }^{13}$ ). The kinetic parameters for the reactions of 9-isothiocyana- 


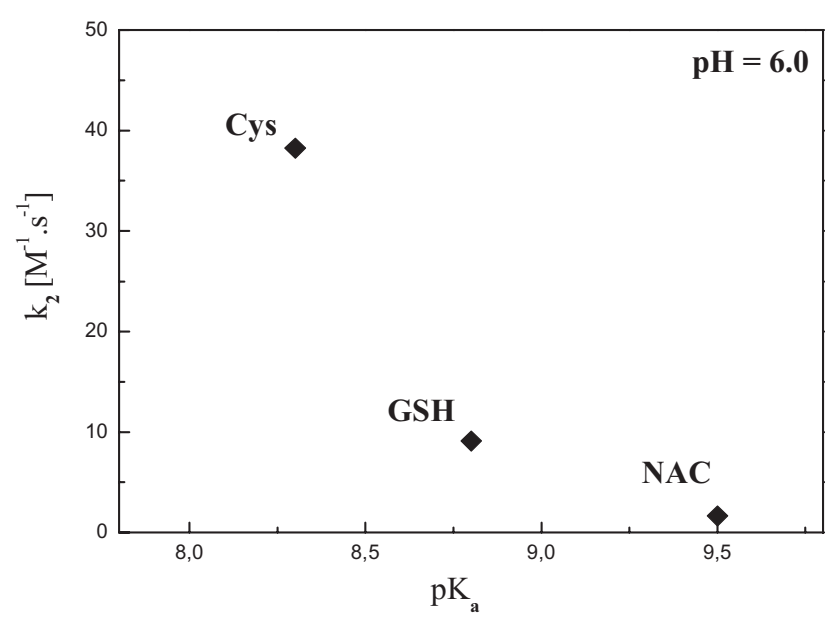

Fig. 1. Plot of $k_{2}\left[\mathrm{M}^{-1} \cdot \mathrm{s}^{-1}\right]$ for the reaction of thiols (cysteine, glutathione and $N$-acetylcysteine) with AcITC against their $\mathrm{pK}_{\mathrm{a}}$ values. Rate constants for the reaction AcITC (0.05 mM) with thiols ( $2.5 \mathrm{mM})$ were estimated in $50 \mathrm{mM}$ Clark-Lubs buffer, $(\mathrm{pH} 6.0)$ containing $30 \%$ of acetonitrile at $25{ }^{\circ} \mathrm{C}$.

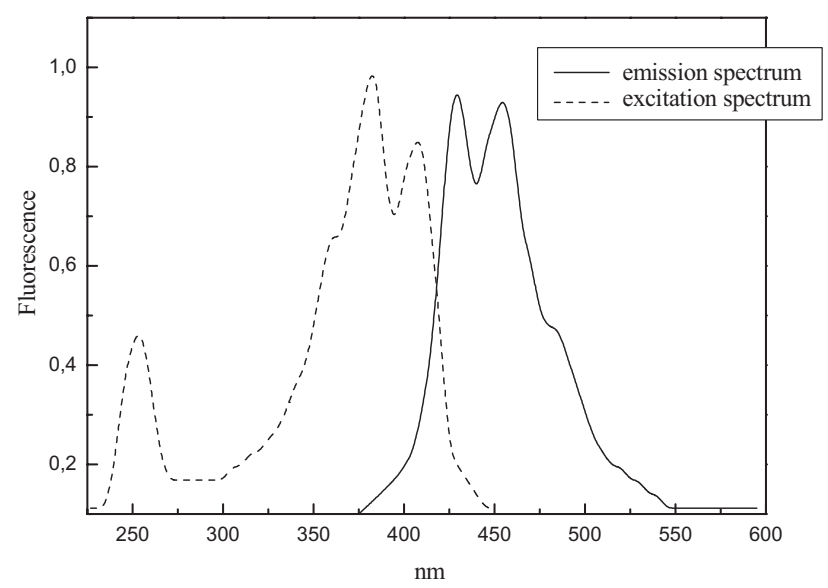

Fig. 2. Emission and excitation spectra of AcITC. Spectra were measured in $50 \mathrm{mM}$ HEPES buffer $(\mathrm{pH} 7.4)$ containing $30 \%$ of dimethylformamide at $21^{\circ} \mathrm{C}$.

toacridine with thiols were estimated and as seen in Fig. 1, the different rank of dissociation of SH- group of thiols influenced of the second-order rate constants. The result is in agreement with generally accepted idea that -NCS group reacts with ionized sulfhydryl group of thiols.

The involvement of thiols in the cytotoxic effects of AcITC was studied on K562 cells line. These erythroleukemic cells express the $\mathrm{p} 210^{\mathrm{BCR}-\mathrm{ABL}}$ fusion protein, that confers resistance to drug-induced apoptosis ${ }^{14}$ and the high level of intracellular $\mathrm{GSH}^{15}$ can be critical in druginduced apoptosis.

At first the effect of AcITC on cell viability has been measured by MTT assay. In spite of the high reactivity of this isothiocyanate the value of $\mathrm{IC}_{50}$ was $29.2 \pm 2.5 \mu \mathrm{M}$.

The studies of $\mathrm{Xu}$ and Thornalley ${ }^{3}$ confirmed the involvement of glutathione in the cytotoxicity of phenethyl isothiocyanate and its cysteine conjugate to HL60 cells. The cellular concentration of GSH in K562 is 5-times higher than in HL60 and that high level of GSH prevent PEITC-induced apoptosis in K562 cells. AcITC is able to inhibit the proliferation of K562 cells and because the acridine derivatives are studied as potential inhibitors of topoisomerases or telomerase ${ }^{16}$, one can suppose that conjugate of AcITC with intracellular thiols could damage DNA or inhibit DNA-related enzymes.

As AcITC acted cytotoxicaly we examined which of death mode (necrosis vs apoptosis) can be induced by different concentration of the substance.

Morphological changes of cells were identified by fluorescent microscopy. Whereas AcITC is a fluorescent substance (Fig. 2), its accumulation and morphological changes of cells were evaluated directly without addition of Hoechst 33342, the dye was used only for observation of a control sample. For identification of necrotic cells (PI-positive), all samples were stained with propidium iodide. Fluorescence microscopy views of K562 cells after incubation with $10 \mu \mathrm{M}$ AcITC are shown in Fig. 3 . AcITC induced morphological changes of cells, plasma membrane blebbing was observed already after 4 hours treatment of cells with $10 \mu \mathrm{M}$ AcITC and the membrane blebbing was more intensive after 24 hours and even chromatin condensation was identified. When the noncytotoxic/cytotoxic concentration of AcITC was used the substance was predominantly accumulated in plasma membrane. Fixation of AcITC in membrane could be a one of reason of restriction of cytotoxicity of this reactive ITC. Cytotoxic concentration of the substance $(50 \mu \mathrm{M})$ induced a considerable necrosis of K562 cell line (65\%) already after $4 \mathrm{~h}$ of incubation.

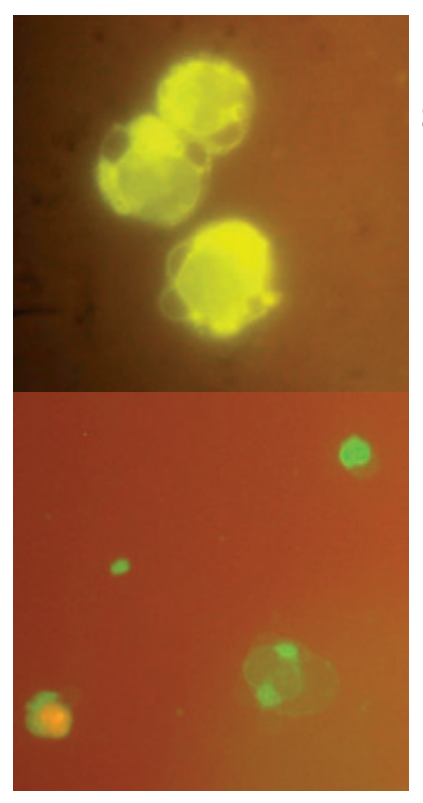

$10 \mu \mathrm{M}$ AcITC

$4 \mathrm{~h}$ of incubation $8 \%$ of necrotic cells

$10 \mu \mathrm{M}$ AcITC

$24 \mathrm{~h}$ of incubation

$20 \%$ of necrotic cells

Fig. 3. Morphological changes of $\mathrm{K} 562$ cells after treatment by AcITC. Cells were treated with $10 \mu \mathrm{M}$ AcITC for 4 or $24 \mathrm{~h}$ and then stained with propidium iodide and examined under a fluorescence microscope. 


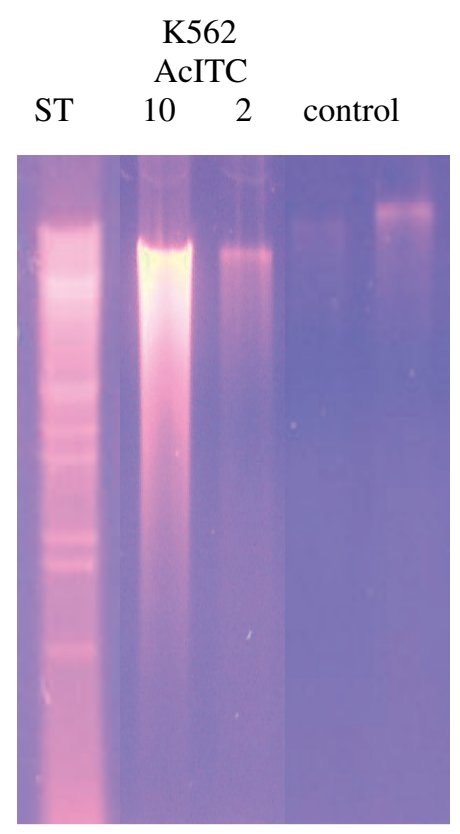

AcITC

102 control cisPt

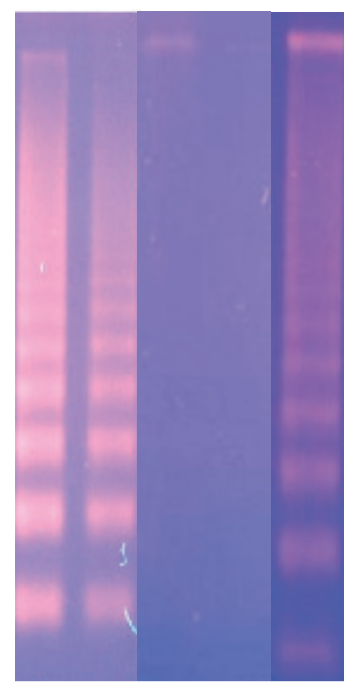

Fig. 4. Agarose gel electrophoresis of DNA fragments from cells treated with AcITC. K562 and L1210 cells were incubated with AcITC $(2$ or $10 \mu \mathrm{M})$ or $8 \mu \mathrm{M}$ cisPt for $24 \mathrm{~h}$. DNA fragmentation was visualized in ethidium bromide after DNA agarose gel electrophoresis. This figure is representative of three experiments. ST, size marker (21226-584 Bp).

Morphological changes of plasma membrane and an extensive membrane blebbing were observed when L1210 cells were treated with AcITC (views are not shown).

In order to estimate whether apoptosis was the mode of cell death, the determination of DNA fragmentation was performed. As seen in Fig. 4, AcITC induced DNA fragmentation and this effect (at $10 \mu \mathrm{M}$ concentration) on L1210 cells was comparable with fragmentation of DNA induced by cisplatin (cisPt).

Results of these experiments confirmed a creation of apoptotic "DNA ladder" if cells were incubated with $10 \mu \mathrm{M}$ AcITC, this concentration was equimolar to intracellular glutathione concentration. If the molar ratio of glutathione to the substance was $1: 5$ then necrosis mode of death was observed. The fate of intracellular thiols in the same conditions was then investigated.

Time-dependent effects of AcITC on the levels of tGSH and LMWT were estimated. The substance was added to cells so that molar ratio of $\mathrm{GSH} /$ substance was $5: 1$ (2 $\mu \mathrm{M}$ AcITC), $1: 1(10 \mu \mathrm{M}$ AcITC) and $1: 5$ (50 $\mu \mathrm{M}$ AcITC) (Fig. 5). $2 \mu \mathrm{M}$ and $10 \mu \mathrm{M}$ AcITC depleted LMWT of cells already after $2 \mathrm{~h}$ incubation while the level of tGSH was only decreased about $25 \%$, respect. $60 \%$. This decrease was temporary and the concentration of tGSH was entirely or partially recovered after 48 hours. $50 \mu \mathrm{M}$ AcITC depleted intracellular thiols and although the level of tGSH was part-regenerated after $48 \mathrm{~h}$ but LMWT level was not restored.

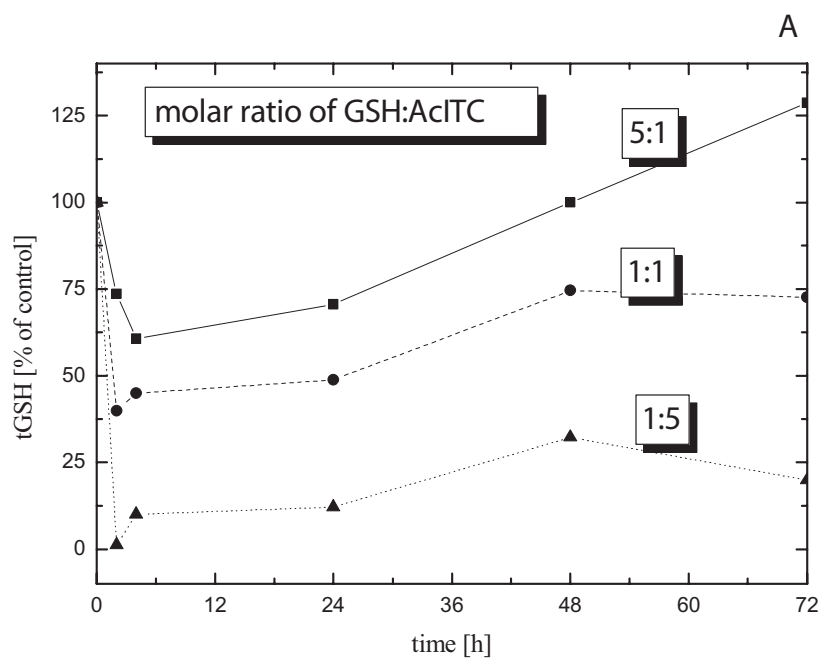

B

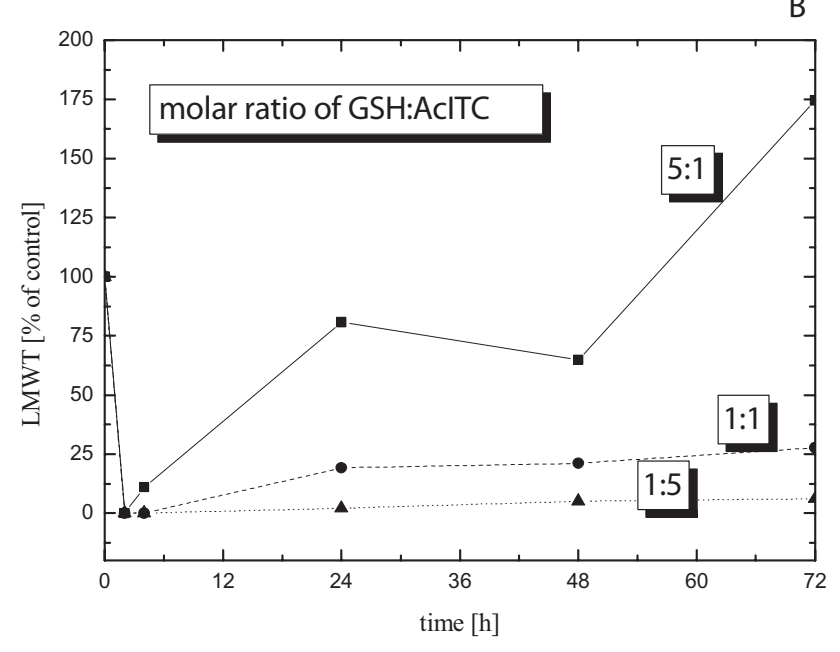

Fig. 5. Effect of AcITC on cellular concentration of tGSH (A) and LMWT (B). K562 cells $\left(2 \times 10^{6} / \mathrm{ml}\right)$ were incubated with AcITC (molar ratio of AcITC to GSH 5:1 (2 $\mu \mathrm{M}$ AcITC), 1:1 (10 $\mu \mathrm{M}$ AcITC) and $1: 5(50 \mu \mathrm{M}$ AcITC) for $0-72 \mathrm{~h} .100 \%$ of tGSH $(\mathrm{LMWT})=29.9 \pm 2.1(30.2 \pm 1.2) \mathrm{nmol} / 10^{6}$ cells.

AcITC decreased level of intracellular LMWT even when molar ratio of ITC and thiols were equal or less than $1 / 5$. The level of glutathione was partially regenerated and only in the case of cytotoxic concentration of AcITC $(50 \mu \mathrm{M})$ it achieved only $10 \%$ of control.

Recently, it was suggested that the cellular redox environment governed by the redox state of the glutathione disulfide (GSSG)/2GSH couple may be one of the final determinants for the execution of apoptosis ${ }^{17}$. Our results confirmed that apoptosis of leukemia cells is possible only if GSH is not entirely depleted.

These finding indicate that glutathione is involved in induction of apoptosis. This acridine derivative can induce apoptosis of cells at least within certain dose that 
only decrease intracellular glutathione, excessive doses (completely depleted intracellular pool of glutathione) induce necrosis rather than apoptosis.

\section{ACKNOWLEDGEMENT}

This work has been supported by VEGA grant 1/1173/ 04.

\section{REFERENCES}

1. Zhang Y, Li J, Tang L. (2005) Cancer-preventive isothiocyanates dichotomous modulators of oxidative stress. Free Rad Biol Med $38,70-77$.

2. Bruggeman IM, Temmink JH, van Bladeren PJ. (1986) Glutathioneand cysteine-mediated cytotoxicity of allyl and benzyl isothiocyanate. Toxicol Appl Pharmacol 83, 349-59.

3. Xu K, Thornalley PJ. (2001) Involvement of glutathione metabolism in the cytotoxicity of the phenethyl isothiocyanate and its cysteine conjugate to human leukaemia cells in vitro. Biochem Pharmacol 61, 165-77.

4. Hudson TS, Stoner GD, Morse MA, Young H, Mallery SR. (2005) Comparison of phenethyl and 6-phenylhexyl isothiocyanate-induced toxicity in rat esophageal cell lines with and without glutathione depletion. Toxicol Lett 155, 427-36.

5. Zhang Y. (2000) Role glutathione in the accumulation of anticarcinogenic isothiocyanates and their glutathione conjugates by murine hepatoma cells. Carcinogenesis 21, 1175-82.

6. Murata M, Yamashita N, Inoue S, Kawanishi S (2000) Mechanism of oxidative DNA damage induced by carcinogenic allyl isothiocyanate. Free Rad Biol Med 28, 797-805.
7. Bauerlein E, Keihl R. (1976) Lipophilic thiourea and thiouracil as inhibitors of oxidative phosphorylation. FEBS Lett 61, 68-71.

8. Kubota S, Horie K, Misra HK, Toyooka K, Uda M, Shibuya M, Terada H. (1985) Synthesis and uncoupling activities of hydrophobic thioureas. Chem Pharm Bull (Tokyo) 33, 662-6.

9. Podhradsky D, Oravec P, Antalik M, Kristian P. (1994) Fluorescence reagents for labelling of biomolecules, part II. Reaction of 9-ITC with amino acid. Collect Chem Commun 59, 213-21.

10. Ellman GL. (1959) Tissue sulfhydryl groups. Arch Biochem Biophys $82,70-77$.

11. Dovinova I, Paulikova H, Rauko P, Hunakova L, Hanusovska E, Tibenska E. (2002) Main targets of tetraaza macrocyclic cooper complex on L1210 murine leukemia cells. Toxicol in Vitro 16, 491-8.

12. McGahon AJ, Martin SJ, Bissonette RP, Mahboubi A, Shi Y Mogil RJ. (1995) The end of the (cell) line: methods for the study of apoptosis in vitro. Methods Cell Biol 46, 153-85.

13. Drobnica L, Kristian P, Augustin J. (1977) The chemistry of the -NCS group, in The chemistry of cyanates and theur thio derivatives, (Ed. Patai S), John Wiley \&Sons.

14. Bedi A, Barber JP, Bedi GC, el-Deiry WS, Sidranski D, Vala MS, Akhtar AJ, Hilton J, Jones RJ. (1995) BCR-ABL-mediated inhibition of apoptosis with delay of G2/M transition after DNA damage: a mechanism of resistance to multiple anticancer agents. Blood 86 , 1148-58.

15. Fernandes RS, Cotter TG. (1994) Apoptosis or necrosis: Intracellular levels of glutathione influence mode of cell death. Biochem Pharmacol 48, 675-81.

16. Demeunynck M, Charmantray F, Martelli A. (2001) Interest of acridine derivatives in the anticancer chemotherapy. Curr Pharm Des 7, 1703-24.

17. Schafer FQ, Buettner GR. (2001) Redox environment of the cell as viewed through the redox state of the glutathione disulfide/glutathione couple. Free Rad Biol Med 30,1191-212. 